\title{
Phenotype Modification and Enhanced Tolerance to Insect Pests by Regulated Expression of a Cytokinin Biosynthesis Gene
}

\author{
Ann C. Smigocki ${ }^{1}$ \\ Plant Molecular Biology Laboratory, U.S. Department of Agriculture, Agricultural Research Service, \\ Beltsville, MD 20705
}

Phytohormones have long been recognized as modulators of growth and differentiation in plants. Early studies with tobacco (Nicotiana tabacum L.) callus culture (Skoog and Miller, 1957) indicated that treatments with auxins and cytokinins, two major classes of phytohormones, could be used to manipulate morphogenesis. The involvement of cytokinins in a variety of plant developmental processes, such as control of senescence, promotion of cell proliferation, chloroplast development, flowering, and plant defense responses, have since been reported (for review, see Mok and Mok, 1994; Smigocki et al., 1993).

Most studies have used exogenous applications to gain a better understanding of the events that lead to the induction of physiological responses by cytokinin. The interpretation of such studies is hampered by problems associated with cytokinin uptake, transport, and metabolism. Therefore, several laboratories have exploited the use of a gene (ipt) from Agrobacterium tumefaciens that induces synthesis of endogenous cytokinins in transformed plant cells (Ainley et al., 1993; Li et al., 1992; Martineau et al., 1994; Medford et al., 1989; Smart et al., 1991; Smigocki, 1991; Smigocki and Hammerschlag, 1991). Isopentenyl transferase, encoded by the ipt gene of the Ti plasmid, catalyzes the condensation of AMP and isopentenyl pyrophosphate to form isopentenyl AMP, a precursor of most other cytokinins (Akiyoshi et al., 1983). Enzymatic activity similar to that encoded by the ipt gene has been observed in plant cytokinin biosynthesis (Blackwell and Horgan, 1994; Chen and Melitz, 1979). However, the plant enzyme has only been partially purified and the corresponding plant gene has yet to be identified and cloned.

\section{PHENOTYPE MODIFICATION VIA EXPRESSION OF THE CYTOKININ BIOSYNTHESIS GENE}

\section{Constitutive overexpression}

Molecular manipulations of the ipt gene for expression in transgenic plants have revealed interesting phenomena. Fusion of the ipt gene with a 35S CaMV (cauliflower mosaic virus) promoter induced constitutive overproduction of cytokinins in transformed Nicotiana tabacum L. and $N$. plumbaginifolia Viv. cells and was correlated with more frequent, rapid, and profuse shoot development than that observed with the unmodified ipt gene (Smigocki and Owens, 1988). In Cucumis sativus L., such a chimeric gene uniquely induced shoot development in transformed cells (Smigocki and Owens, 1988). However, in similar studies with petunia (Petunia hybrida Vilm.) and peach [Prunus persica (L.) Batsch], no shoots were regenerated from transformed cells (Klee et al., 1987; Smigocki and Hammerschlag, 1991). Propagation of some of the transformed Nicotiana sp. shoots in tissue culture induced their dedifferentiation into unorganized callus cells, some of which eventually died (Smigocki and Owens, 1989). Cytokinin concentrations in these unorganized tissues corresponded to some of the highest zeatin and zeatinriboside levels determined for a particular group of transformants. From these observations, we speculate that plant cells can be induced to undergo morphogenesis with increasing endogenous cytokinin concentrations; however, cyto-

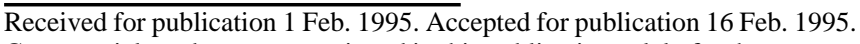
Commercial products are mentioned in this publication solely for the purpose of providing specific information. Mention of a company name and/or product does not constitute a guarantee or warranty of its product by the U.S. Dept. of Agriculture or an endorsement by the department over products of other companies not mentioned. kinin levels can become unfavorably high and ultimately detrimental to the cell's ability to differentiate and survive. Another major drawback to constitutive overproduction of cytokinins is the suppression of root development irrespective of shoot regeneration. Most recently, this phenomenon has been overcome by spatial and temporal regulation of cytokinin gene expression (ipt) in transgenic plants (Ainley et al., 1993; Li et al., 1992; Martineau et al., 1994; Medford et al., 1989; Smart et al., 1991; Smigocki, 1991; Smigocki et al., 1993).

\section{Transient overexpression}

Transient overproduction of cytokinins using gene promoters regulated by environmental or developmental factors, or both, did not prevent root development on ipt-transformed shoots. In several reports, rooted plantlets were obtained from shoots transformed by the ipt gene under control of promoters from various heat shock genes (Ainley et al., 1993; Medford et al., 1989; Smart et al., 1991; Smigocki, 1991); an auxin-inducible SAUR gene (Li et al., 1992); a woundinducible, tuber-specific proteinase inhibitor IIK gene (Smigocki, 1995; Smigocki et al., 1993); and a fruit-specific tomato (Lycopersicon esculentum Mill.) gene (Martineau et al., 1994). Regenerants transformed with the heat- and auxin-inducible promoters were generally greener, shorter, had a less-developed root system, reduced leaf width, increased growth of axillary buds, and, in some cases, abnormal flower development - all characteristics associated with higher endogenous cytokinin concentration. This result was expected due to the documented low levels of transcription of these promoters in the uninduced state during plant growth and development. Conversely, delay of expression of an ipt gene construct in tomato until fruit maturation and ripening yielded phenotypically normal plants, except for some fruit that were mottled with green islands on otherwise deep-red, ripe fruit. Surprisingly, plants transformed with the wound-inducible ipt gene construct were characterized by early bolting, pronounced apical dominance, increased height and leaf size, thinner leaves, and reduced chlorophyll content (Smigocki, 1995). Except for an underdeveloped root system and reduced chlorophyll content (Ainley et al., 1993; Li et al., 1992), these phenotypes have not been previously associated with expression of the ipt gene or increased endogenous cytokinin levels and are more typical of increased auxin levels.

The observed variable phenotypes of ipt-transformed plants stress the importance of organ, tissue, and cell specificity and of temporal cytokinin production on plant growth and development. These studies also clearly establish that regulated expression of cytokinin biosynthesis genes will not prevent whole-plant regeneration; thus, this approach potentially can be used to manipulate commercially acceptable plant physiological processes.

\section{CYTOKININ-INDUCED DELAY OF SENESCENCE}

A general view has emerged that root tips and exudates contain cytokinins that are responsible for controlling senescence (Nooden and Letham, 1993). Reduction of cytokinin supply from the root to the shoot, when growth of the plant ceases, appears to be one of the causes of senescence. A sink-to-source shift for mature leaves may further enhance the senescence of shoots by lowering the capacity of the leaves to retain metabolites and by redirecting the flow of assimilates to the cytokinin-rich, growing fruit.

The importance of delayed senescence in increasing plant yield, under certain circumstances, has been demonstrated in studies on 
slow-senescing mutants of several crops, including sorghum [Sorghum bicolor (L.) Moench] and tomato (Ambler et al., 1987). As an alternative, biotechnological approaches can be used to manipulate plant growth and senescence. Directed expression of $i p t$ transgenes at least partially delayed senescence in plants. Smart et al. (1991) fused the ipt gene to the soybean (Glycine max L.) heat shock promoter and demonstrated delayed onset of senescence in individually heat-treated leaves of transformed plants. However, this was a localized response that subsequently induced earlier death of adjacent, nonheat-shocked leaves. In the other studies, the senescence process was not well controlled because ipt gene expression was not targeted to any particular tissue or organ and the promoters used were leaky (Ainley et al., 1993; Li et al., 1992; Medford et al., 1989; Smigocki, 1991).

Control of ipt gene expression by a developmentally regulated promoter from a gene that is, for example, activated in the roots upon cessation of growth would potentially extend the life of the plant. Interestingly, the expression of the potato (Solanum tuberosum L.) proteinase inhibitor gene is wound-inducible in leaves and becomes constitutively expressed in tubers and flowers in the latter stages of plant growth; it has been similarly regulated in transgenic tobacco (Lorbeth et al., 1992; Ryan, 1992). Transformation of tobacco with the ipt gene fused to this wound-inducible promoter delayed whole-plant senescence in flowering plants (Smigocki, 1995; Smigocki et al., 1993). The onset and level of root ipt gene expression differed between $N$. plumbaginifolia and N. tabacum transformants and was correlated with the various resulting phenotypes. A slight increase in root ipt transcript level was detected only during the rosette stage but not in bolted N. tabacum plants; whereas in N. plumbaginifolia, root expression was limited to the bolted plants and was not apparent at the rosette stage even after direct wounding of the roots. Basal leaf greening and emergence of numerous lateral shoots from the lower stem sections of flowering $N$. plumbaginifolia plants followed the increased root ipt gene expression and corresponded to the delay of whole-plant senescence by 1 to 3 months. The earlier expression of the ipt gene in $N$. tabacum roots induced the appearance of other cytokinin effects, such as leaf greening, thicker stems, and shorter plants, in addition to the delay of senescence, as observed for $N$. plumbaginifolia, at an earlier developmental stage of growth.

In conclusion, it appears likely that root expression of the ipt gene favors the delay of the onset of whole-plant senescence. The earlier the expression occurs in plant development, the more likely it is that other effects of elevated cytokinin levels also will be observed. However, the potential to delay senescence in economically important crops by introducing this gene construct or others, which will allow for rootspecific ipt gene expression upon cessation of plant growth, may be of agronomic significance for increasing productivity.

\section{CYTOKININ INVOLVEMENT IN PEST AND DISEASE RESISTANCE}

Cytokinins, as well as other plant growth regulators, have commercial applications as bioregulators and, in combination with endogenous hormones, may protect plants from pests and pathogens by inducing physiological changes in the plants (Hallahan et al., 1992; Hedin et al., 1988a, 1988b; Thomas and Blakesley, 1987). That plant hormones may have a major role as control agents in host $\times$ parasite interactions is suggested by effects of exogenously added phytohormones on biochemical characteristics indicative of a hypersensitive response to bacterial and fungal pathogens and on the extent of lesion development determined in vivo during infections (Bevan and Northcote, 1979; Faccioli et al., 1984; Mills et al., 1986; Plich, 1976). In addition, manipulation of endogenous cytokinin levels due to expression of the ipt gene in transformed, nonrooting tobacco shoot lines was shown to up-regulate the expression of defense-related mRNAs (Memelink et al., 1987). Cytokinins influence secondary metabolic pathways, products of which exhibit insecticidal properties (Binns et al., 1987; Orr and Lynn, 1992; Teutonico et al., 1991) that are being evaluated currently in crop protection studies, either by conventional plant breeding or by genetic engineering (Gatehouse et al., 1992; Hallahan, 1992).

Because the present focus for crop improvement attempts to combine the effects of natural defense mechanisms of plants and biotechnology, we evaluated cytokinin's role as a modulator of insect resistance in $N$. plumbaginifolia carrying the wound-inducible ipt transgene. Mechanical wounding and insect feeding induce the expression of this promoter (Johnson et al., 1989; Lorberth et al., 1992); therefore, transgenic plants were exposed to the herbivorous pest, tobacco (tomato) hornworm (Manduca sexta L.), and a virus-transmitting pest, the green peach aphid (Myzus persicae Sulzer), to evaluate the influence of wound-induced ipt expression on insect feeding and development. When the M. sexta larvae were fed leaf material from flowering transgenic plants, they consumed significantly less than larvae feeding on leaves from control plants (Smigocki et al., 1993). Similar results were obtained when whole plants were infested with the larva. The effect on green peach aphid nymphs was more significant. Only $\approx 50 \%$ of newly hatched nymphs developed into adult females when feeding on transgenic plants, and of those that reached adulthood, fewer were able to reproduce as compared with controls. In addition, the level of insect tolerance in transgenic plants was enhanced further by boosting the endogenous cytokinin levels with exogenous zeatin applications that had proved ineffective in nontransformed plants.

Storti et al. (1994) introduced the Agrobacterium ipt gene into a tomato cultivar that is normally susceptible to the fungal pathogen Fusarium oxysporum. They observed that a shift of the phytohormone equilibrium toward a higher cytokinin concentration induced enhanced resistance to the fungus.

Little is known about the mode of action of the ipt gene on enhanced disease resistance, but involvement of secondary metabolites is suspected. Bioassays of fractionated plant extracts from transgenic plants will aid in identifying any compound(s) that may be involved in natural plant defense properties and the role of cytokinins in modulation of the corresponding biosynthetic pathway(s).

\section{CONCLUSION}

To date, only a few plant physiological processes manipulated by cytokinins are recommended for practical applications. For example, a commercial growth regulator mixture is used to improve the appearance of 'Red Delicious' apples (Malus domestica Borkh.), and seaweed extracts with high levels of zeatin-type cytokinins are used commercially on several crops to increase yields (Thomas and Blakesley, 1987). The most common use for cytokinins is as a component of culture media used in plant micropropagation (Thomas and Blakesley, 1987). Despite their well-documented involvement in the numerous aspects of plant growth and development, little is known about the fundamental mechanisms of cytokinin action. A better understanding of cytokinins may potentiate future use for major commercial objectives.

Clearly, a large part of cytokinin action involves changes in gene expression patterns (Chen and Leisner, 1984; Crowell et al., 1990; Harding and Smigocki, 1994). Some of the specific mRNAs whose abundance increases in response to exogenous application of a cytokinin include those encoding a chlorophyll $\mathrm{a} / \mathrm{b}$ binding protein, a small subunit of ribulose-bisphosphate carboxylase-oxygenase (Flores and Tobin, 1988), nitrate reductase (Lu et al., 1990), a hydroxyproline-rich glycoprotein (Watillon et al., 1991), a multiple stimulus response protein (Dominov et al., 1992), and a small heat-shock protein (Harding and Smigocki, 1994). Our interest has been to correlate cytokininresponsive gene expression with one of the processes regulated by cytokinins (Harding and Smigocki, 1994; Smigocki, 1991; Smigocki and Owens, 1988). From a library prepared from mRNA extracted from ipt-transformed plant tissues induced to produce cytokinin, a set of cDNA clones was isolated using a subtracted cDNA probe enriched for cytokinin up-regulated genes. Future prospects include identifying these genes and determining their function as they relate to cytokinin's role in plant growth and development and natural defense mechanisms.

\section{Literature Cited}

Ainley, W.M., K.J. NcNeil, J.W. Hill, W.L. Lingle, R.B. Simpson, M.L. Brenner, R.T. Nagao, and J.L. Key. 1993. Regulatable endogenous produc- 
tion of cytokinins up to 'toxic' levels in transgenic plants and plant tissues. Plant Mol. Biol. 22:13-23.

Akiyoshi, D.E., R.O. Morris, R. Hinz, B.S. Mischke, T. Kosuge, D. Garfinkel, M.P. Gordon, and E.W. Nester. 1983. Cytokinin/auxin balance in crown gall tumors is regulated by specific loci in the T-DNA. Proc. Natl. Acad. Sci. USA 80:407-411.

Ambler, J.R, P.W. Morgan, and W.R. Jordan. 1987. Genetic regulation of senescence in a tropical grass, p. 43-53. In: W.W. Thomson, E.A. Nothnagel, and R.C. Huffaker (eds.). Plant senescence: Its biochemistry and physiology. Amer. Soc. Plant Physiol., Rockville, Md.

Bevan, M. and D.H. Northcote. 1979. The interaction of auxin and cytokinin in the induction of phenylalanine ammonia-lyase in suspension cultures of Phaseolus vulgaris. Planta 147:77-81.

Binns, A.N., R.H. Chen, H.N. Wood, and D.G. Lynn. 1987. Cell division promoting activity of naturally occurring dehydrodiconiferyl glucosides: Do cell wall components control cell division. Proc. Natl. Acad. Sci. USA 84:980-984.

Blackwell, J.R. and R. Horgan. 1994. Cytokinin biosynthesis by extracts of Zea mays. Phytochemistry 35:339-342.

Chen, C-M. and S.M. Leisner. 1984. Cytokinin-modulated gene expression in excised pumpkin cotyledons. Plant Physiol. 77:99-103.

Chen, C-M. and D.K. Melitz. 1979. Cytokinin biosynthesis in a cell-free system from cytokinin-autotrophic tobacco tissue cultures. FEBS Lett. 107:15-20.

Crowell, D.N., A.T. Kadlecek, M.C. John, and R.M. Amasino. 1990. Cytokinin-induced mRNAs in cultured soybean cells. Proc. Natl. Acad. Sci. USA 87:8815-8819.

Dominov, J.A., L. Stenzler, S. Lee, J.J. Schwarz, S. Leisner, and S.H. Howell. 1992. Cytokinins and auxins control the expression of a gene in Nicotiana plumbaginifolia cells by feedback regulation. Plant Cell 4:451-461.

Faccioli, G., C. Rubies-Autonell, and R. Albertini. 1984. Role of cytokinins in the acquired resistance of Chenopodium amaranticolor towards an infection of tobacco necrosis virus. Phytopathol. Mediterranea 23:15-33.

Flores, S. and E.M. Tobin. 1988. Cytokinin modulation of LHCP mRNA levels: The involvement of post-transcriptional regulation. Plant Mol. Biol. 11:409-415.

Gatehouse, A.M.R., D. Boulter, and V.A. Hilder. 1992. Potential of plant derived genes in the genetic manipulation of crops for insect resistance, $p$. 155-181. In: A.M.R. Gatehouse, V.A. Hilder, and D. Boulter (eds.). Plant genetic manipulation for crop protection. Redwood Press, Melksham, U.K.

Hallahan, D.L., J.A. Pickett, L.J. Wadhams, R.M. Wallsgrove, and C. Woodcock. 1992. Potential of secondary metabolites in genetic engineering of crops for resistance, p. 212-248. In: A.M.R. Gatehouse, V.A. Hilder, and D. Boulter (eds.). Plant genetic manipulation for crop protection. Redwood Press, Melksham, U.K

Harding, S.A. and A.C. Smigocki. 1994. Cytokinins modulate stress response genes in isopentenyl transferase-transformed Nicotiana plumbaginifolia plants. Physiol. Plant. 90:327-333.

Hedin, P.A., J.C. McCarty, A.C. Thompson, J.N. Jenkins, D.H. Smith, R.L. Shepherd, and W.L. Parrott. 1988a. Plant bioregulator induced increases in the protein content of cotton plant tissues. J. Agr. Food Chem. 36:742-745.

Hedin, P.A., W.P. Williams, F.M. Davis, and A.C. Thompson. 1988b. Effects of bioregulators on nutrients, insect resistance, and yield of corn (Zea mays L.). J. Agr. Food Chem. 36:746-748.

Johnson, R., J. Narvaez, G. An, and C. Ryan. 1989. Expression of proteinase inhibitors I and II in transgenic tobacco plants: Effects on natural defense against Manduca sexta larvae. Proc. Natl. Acad. Sci. USA 86:9871-9875.

Klee, H.J., R.B. Horsch, and S.G. Rogers. 1987. Agrobacterium-mediated plant transformation and its further application to plant biology. Annu. Rev. Plant Physiol. 38:467-486.

Li, Y., G. Hagen, and T.J. Guilfoyle. 1992. Altered morphology in transgenic tobacco plants that overproduce cytokinins in specific tissues and organs. Developmental Biol. 153:386-395.

Lorberth, R., C. Dammann, M. Ebneth, S. Amati, and J. Sanchez-Serrano. 1992. Promoter elements involved in environmental and developmental control of potato proteinase inhibitor II expression. Plant J. 2:477-486.
Lu, J-I., J.R. Ertl, and C-M. Chen. 1990. Cytokinin enhancement of the light induction of nitrate reductase transcript levels in etiolated barley leaves. Plant Mol. Biol. 14:585-594.

Martineau, B., C.M. Houck, R.E. Sheehy, and W.R. Hiatt. 1994. Fruit-specific expression of the A. tumefaciens isopentenyl transferase gene in tomato: Effects on fruit ripening and defense-related expression in leaves. Plant J. 5:11-19.

Medford, J.I., R. Horgan, Z. El-Sawi, and H.J. Klee. 1989. Alterations of endogenous cytokinins in transgenic plants using a chimeric isopentenyl transferase gene. Plant Cell 1:403-413.

Memelink, J., J.H.C. Hoge, and R.A. Schilperoort. 1987. Cytokinin stress changes the developmental regulation of several defence- related genes in tobacco. EMBO J. 6:3579-3583.

Mills, P.R., J. Gussine, and R.S.K. Wood. 1986. Induction of resistance in cucumber to Colletotrichum lagenarium by 6-benzylaminopurine. J. Phytopathol. 116:11-17.

Mok, D.W. and M.C. Mok. 1994. Cytokinins: Chemistry, activity, and function. CRC Press, Boca Raton, Fla.

Nooden, L.D. and D.S. Letham. 1993. Cytokinin metabolism and signalling in the soybean plant. Austral. J. Plant Physiol. 20:639-653.

Orr, J.D. and D.G. Lynn. 1992. Biosynthesis of dehydrodiconiferyl alcohol glucosides: Implications for the control of tobacco cell growth. Plant Physiol. 98:343-352.

Plich, M. 1976. Influence of growth regulators on the development of collar knot disease caused by the fungus Phytophthora cactorum in apple trees. Fruit Sci. Rpt. 3:33-42.

Ryan, C.A. 1992. The search for the proteinase inhibitor-inducing factor, PIIF. Plant Mol. Biol. 19:123-133.

Skoog, F. and C.O. Miller. 1957. Chemical regulation of growth and organ formation in plant tissues cultured in vitro. Symp. Soc. Expt. Biol. 11:118-130.

Smart, C.M., S.R. Scofield, M.W. Bevan, and T.A. Dyer. 1991. Delayed leaf senescence in tobacco plants transformed with $t m r$, a gene for cytokinin production in Agrobacterium. Plant Cell 3:647-656.

Smigocki, A.C. 1991. Cytokinin content and tissue distribution in plants transformed by a reconstructed isopentenyl transferase gene. Plant Mol. Biol. 16:106-115.

Smigocki, A.C. 1995. Expression of a wound-inducible cytokinin biosynthesis gene in transgenic tobacco: Correlation of root expression with induction of cytokinin effects. Plant Sci. (In press.)

Smigocki, A.C. and F.A. Hammerschlag. 1991. Regeneration of plants from peach embryo cells infected with a shooty mutant strain of Agrobacterium. J. Amer. Soc. Hort. Sci. 116:1092-1097.

Smigocki, A.C., J.W. Neal, I. McCanna, and L. Douglass. 1993. Cytokininmediated insect resistance in Nicotiana plants transformed with the ipt gene. Plant Mol. Biol. 23:325-335.

Smigocki, A.C. and L.D. Owens. 1988. Cytokinin gene fused with a strong promoter enhances shoot organogenesis and zeatin levels in transformed plant cells. Proc. Natl. Acad. Sci. USA 85:5131-5135.

Smigocki, A.C. and L.D. Owens. 1989. Cytokinin-to-auxin ratios and morphology of shoots and tissues transformed by a chimeric isopentenyl transferase gene. Plant Physiol. 91:808-811.

Storti, E., P. Bogani, P. Bettini, P. Bittini, M.L. Guardiola, M.G. Pellegrini, D. Inze, and M. Buiatti. 1994. Modification of competence for in vitro response to Fusarium oxysporum in tomato cells. II. Effect of the integration of Agrobacterium tumefaciens genes for auxin and cytokinin synthesis. Theor. Appl. Genet. 88:89-96.

Teutonico, R.A., M.W. Dudley, J.D. Orr, D.G. Lynn, and A.N. Binns. 1991. Activity and accumulation of cell division- promoting phenolics in tobacco tissue cultures. Plant Physiol. 97:288-297.

Thomas, T.H. and D. Blakesley. 1987. Cytokinins-Plant hormones in search of a role-Practical and potential uses of cytokinins in agriculture and horticulture. Monogr. British Growth Regulat. Group 14:69-83.

Watillon, B., R. Kettmann, P. Boxus, and A. Burny. 1991. Characterization of two gene transcripts modulated by cytokinins in micropropagated apples (Malus domestica [L.] Borkh) plantlets. Plant Physiol. 96:479-484. 